\title{
Blindness: physical or spiritual? An attempt at an interdisciplinary analysis
}

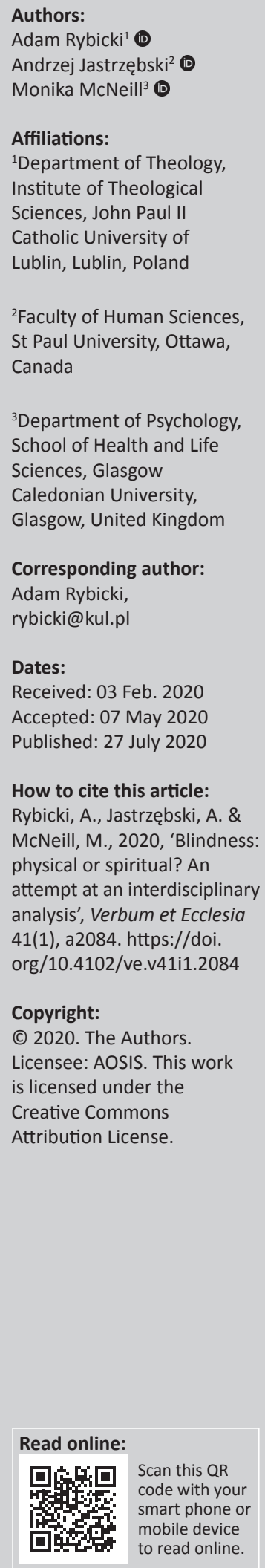

Authors:

Adam Rybicki ${ }^{1}$

Affiliations:

Department of

Sciences, John Paul II

Catholic University of

${ }^{2}$ Faculty of Human Sciences, St Paul University, Ottawa,

${ }^{3}$ Department of Psychology, School of Health and Life ciences, Glasgow

Caledonian University,

sgow, United Kingdom

Adam Rybicki,

Dates:

Received: 03 Feb. 2020

Accepted: 07 May 2020

How to cite this article: Rybicki, A., Jastrzębski, A. \& physical or spiritual? An attempt at an interdisciplinary analysis', Verbum et Ecclesia 41(1), a2084. https://doi. org/10.4102/ve.v41i1.2084 \section{Licensee: AOSIS. This work is licensed under the Creative Commons Attribution License.

This article focuses on the issue of the weakness of human perception, which raises questions about the reasons for not recognising certain people and the mistakes related to such, at the level of both the physical and spiritual senses. The main issue here is why we do not recognise the face and figure of another person. One of the classic examples of this phenomenon is the meeting of Jesus with his disciples on the road to Emmaus (Lk 24:13-35), where first Jesus is inexplicably unnoticed by the disciples, and then unrecognised. We attempt an interdisciplinary analysis of this event. Theological interpretations of the causes of this disability (e.g. as the effects of original $\sin$ ) are insufficient, which is why they are supplemented with philosophical and anthropological interpretations, as well as contemporary empirical research on facial recognition conducted in the area of psychology. The article arrives at the conclusion that the results of the research on the defects in the mechanisms of perception found by psychologists, and a philosophical, as well as theological, analysis of human nature and theology do not contradict each other, but rather create a more complex (exhaustive) answer to the question posed.

Intradisciplinary and/or interdisciplinary implications: A strictly theological interpretation of human behaviour stems from original sin in that it has damaged human nature by constricting its cognitive abilities. This article goes beyond such a restrictive approach in exploring this absence of vision by including both the philosophical and empirical approaches used in psychology.

Keywords: Emmaus; blindness; perception; distortion; interdisciplinary analysis.

\section{Introduction}

In the theological anthropology of the Church of the first centuries, one of the key issues was the 'doctrine of spiritual senses', the issue of the connections between the spiritual senses and the bodily senses and their relationship with other internal human faculties. Reflecting on the spiritual senses, early Christian writers agreed on their imperfect functioning, faults, proneness to misinterpretation, etc. They referred to biblical scenes in which the characters described did not see or recognise something, or else they were wrong in identifying people, objects or situations. The reflection that was born on the canvas of these examples led to questions about the nature and reason(s) for these dysfunctions or mistakes. As for the main source of impairment of the senses, there seems to have been agreement: it was sin that caused all possible disorders and distortions in human functioning. However, the question about the nature of these dysfunctions is still valid. It is a question concerning the elements of a rather complex perception process, which causes a person to make mistakes in their perception of reality. This text is an attempt to look at the issue of the deficiency of human visual perception, particularly from a theological point of view, in the context of other areas of investigation, that is, philosophy and psychology.

One important methodological issue of this article is the question of how to differentiate the bodily senses from the so-called 'spiritual senses'. The answer is not as simple as it might seem, because, in theology, their mutual relationship is understood manifold: sometimes they are seen as two divergent realities; other times both are understood as centres of perception connected in an intimate way, and yet as two aspects of one bodily-spiritual element of human nature. St Paul's concept of external and internal man deeply inspired Christian thought, which resulted in, amongst other things, the attribution of the internal senses to the 'internal man' and the bodily senses to the 'external man'. Does a disability in the external senses relate to a disability in the spiritual senses? It is usually beneficial to present a case study when examining a particular area. In the area being explored here, those biblical narratives where people do not recognise the Risen Christ are a perfect exemplification of the defect of human perception, a kind of 'diagnostic situation'. One of the most intriguing issues is how people recognised, or failed to recognise, Christ after the Resurrection, and, especially, why the disciples did not. The answers can be explored in at least two ways: the first is 
Christology, which describes the nature of Christ before and after the Resurrection, and the second is spiritual theology, which deals with the human spiritual experience, including the perception of spiritual realities. The discussion in this text leans more towards the theology of spirituality, by focusing on the human experience. The theology of spirituality, as an exploration of the spiritual experience, is a reasonably novel area of theology which is developing in a continuous relationship with psychology, philosophy and other humanities. It is also possible - and necessary - to treat the problem outlined in this text as an interdisciplinary subject, since, in this area of research, theology will encounter philosophical (epistemology, ethics), psychological (the psychology of perception) and even biological questions.

The structure of this article corresponds, in a way, to the chronology of the inclusion of individual areas of research and points of view, in an attempt to study the issues pertaining to blindness. The first section shows the philosophical perspective. In the second, we turn to biblical studies, beginning with a general outline of biblical typhlology, as it already sheds some light on the perception of human disabilities (especially, in this case, the sense of sight). Next, there will be a detailed biblical exegesis regarding the most important pericope in this respect, that is, Jesus' encounter with the disciples going to Emmaus. This section has been supplemented by an interdisciplinary analysis, including contemporary results of psychological research on the mechanisms of human perception.

Such a construction of the argument shows very clearly that the development of the humanities and social sciences enable us to look at the issue of the weakness of human perception from a broader perspective. The interdisciplinary character, strongly emphasised in this article, makes it possible to look much deeper, not only at the problem discussed, but at many other questions of a similar nature. The article is an opening for discussion and an invitation for theologians to engage in further dialogue with the other sciences.

\section{The philosophical perspective}

In Western culture and science, the division into five senses comes from Aristotle, for whom the primary sense was sight. It is accepted that sight is at the very top of the hierarchy of senses, ordered as follows: sight, hearing, smell, taste and touch (Aristotle 1933), although Aristotle was not always consistent in this ranking. The Christian way of thinking adopted this hierarchy and it is still in place till this very day. An additional argument for distinguishing eyesight amongst the senses is the fact that the eschatological culmination of Christian spiritual life, that is, meeting God in heaven, is called visio beatifica - beatific vision, rather than hearing or touch. Moreover, from the psychological point of view sight seems to be the most important of the senses; however, there may be some cultural differences in terms of the frequency of use and the sophistication of communicating different sensory information (Majid et al. 2018).
Another argument in favour of eyesight is the fact that, in his theological reflections, St Thomas Aquinas uses the metaphor of seeing in a cognitive context, which he does not do when talking about hearing or any other sensory experience. In St Thomas' description of the external senses, eyesight is the best and, indeed, the only sense that does not require any natural or physical change in an organ nor in its subject; therefore, seeing is the best metaphor, because its immaterial nature makes it the closest of all the senses to immaterial intellectual cognition (Aquinas, Summa theologica, Suppl., q. 92).

The Greek name for sight disorders comes from the word tyflos (blind). Greek dictionaries indicate different nuances of this concept, indicating that it can be understood literally, but also metaphorically. In this sense, what blinded was also called blind, for example, wealth, or the god of wealth (Plutos), of love (Eros) or of war (Ares). One could also become blind through one's pride or ignorance. The broad, metaphorical meaning (e.g. intellectual or moral) of the concept of tyflos is also pointed out by etymology researchers of contemporary concepts (Scharge 1985).

Ancient European culture is full of records of people who are visually impaired or completely blind. We can read about them in the works of Seneca, Euripides, Homer, Thucydides, Ovid, Aristotle and Herodotus. These ancient writers understood vision impairment both metaphorically and figuratively, as applied to immaterial values, which are subjects of study in ethics and axiology. The ancients had already recognised 'philosophical blindness', which was simply called 'spiritual' in Sophocles' King Oedipus; however, they did not yet know of sacred-related blindness. Terms such as 'eyes of the spirit' come from those times as well, and the word 'blind' is often used to describe the cognitive activities of the mind (nous in Greek). One such example is the soul, which focuses too much on one object, being described by Democritus as becoming blind to other matters. In Plato's thought, blindness means not being able to see spiritual realities. Rich people, those in love and those who are not philosophers are often called blind (Plato, Leges V 731). Moreover, other philosophers consider as blind those who see existence and non-existence as one. For Epictetus, blind is the person who does not know who they are and why they exist, or does not know what is good and what is bad. On the other hand, from the religious perspective, blindness (total or partial) in ancient times was treated as a punishment imposed by the deities, one that could also be withdrawn (e.g. Plutarch, Parallel Lives, 17). As Diodorus Sicilian recalls (Historical Library I 25, 5), Isis was considered a goddess who could restore full vision to anyone, if that person asked for it. Furthermore, the goddess Bona Dea had a similar power; she had the nickname Oc(u)lata, which means 'lady of the eyes'. Later, however, the ancient writers (e.g. Quintus of Smyrna, Plutarch, Pausanias, Spartan) began to interpret the whole phenomenon of the loss or restoration of vision more naturalistically, without associating the intervention of the gods with such occurrences (Tronina 1997). 


\section{Biblical typhlology}

A brief summary of ancient thought is justified here, because we cannot analyse the biblical description of things in isolation from ancient culture, and this relationship is already visible in the book of Genesis. From the very outset, however, it should be stipulated that 'biblical typhlology', like all Bible teaching, has a slightly different feature in the Old Testament and in the New. 'Biblical typhlology' is a concept proposed by one of the most outstanding Polish biblical scholars, Antoni Tronina. By this, the author understands the whole of biblical teaching in relation to this disability - the blindness of human sight - together with a complete lack of sight. The author also states that, according to the biblical view, 'biblical typhlology' is not only a literal dimension, but also - even more emphasised, especially in the New Testament - a spiritual dimension. In this way, typhlology is no longer just a research issue for biblical theology (or medicine), but also an area of research for the theology of spirituality.

The first book of the Bible, the book of Genesis, in the first sentences of the description of man already indicates that the subject of 'seeing' and 'blindness' will be inscribed in human existence, in the drama of human fate and human choices. The phrase 'open your eyes' here prophesies the topic of spiritual blindness, which henceforth is present in many books in the Bible. Satan is already present in the book of Genesis, who promises to 'open man's eyes' to make man like God, but the scene ends with a completely different 'opening of the eyes', leading to a statement about man's own nudity, meaning guilt and shame (Gn 2:25-37). The loss of cognitive powers (specifically, sight) also occurs in the story of Lot, where the meaning of the term sanwerim (blinded, confused) appears. When the books of Exodus and Deuteronomy tell us about the exercise of judicial power, it states that 'power blinds', and that, especially, the immoral conduct of judges, that is, bribery and corruption, has the power to blind (Ex 23:1-8; Dt 16:19). The link between the physical and moral-spiritual aspects of sight impairment is also visible in the Old Testament prohibition that a blind person should not be admitted to the priesthood and offer sacrifices to God in the temple (Lv 21:17-20). As for sacrificial animals, even they should not have any blemish, and amongst these flaws the imperfection of the sense of sight is mentioned first (Lv 22:22). In the further books of the Old Testament, the theology of the handicap of sight changes slightly: this handicap is no longer a punishment from God, but rather a picture of spiritual disability caused by sin. That is why the blind, the visually impaired etc. become objects of special protection of religious communities (Tronina 1997).

Interesting discussions revolve around the biblical healing scene in Bethsaida (Mk 8:22-26). Jesus heals a blind man, after which the patient states that he sees 'people like trees', meaning that his vision was blurred, which makes Jesus repeat the healing actions until the man's sight was clear (e.g. Hull 2001). The symbolic significance of the scene is indicated here by a number of factors, in particular by not mentioning the healed man's name or the context of the event. In contrast, theological discussions around this scene concern the nature of the miracle: by definition, the miracles present in the Bible are meant to be a confirmation of God's omnipotence; this scene, however, as rationalists maintain, is rather a denial of that omnipotence, because Jesus repeats the healing, rather than making it work the first time. Various aspects of visual impairment in the New Testament are directly related to supernatural reality and Jesus appears as the one who heals and restores sight in all of its dimensions. There are many evangelical events showing both people with visual impairments and the significance of Jesus as a person, and so it is worth focusing on the most symptomatic ones. The first scene of great spiritual significance, despite the fact that it concerns physical disability, is in the Gospel of John, namely the scene of the healing of the blind man in the Siloam pond (Jn 9). Jesus faces the blind man, but people also ask him about the cause of his disability: 'Rabbi, who sinned, this man or his parents, that he was born blind?' (Jn 9:2). Jesus, however, strongly contradicts this line of reasoning, pointing out that the question is wrong. He stresses that one should not ask about the cause, but rather the purpose and sense of the handicap. Jesus' conversation with the healed person is equally important from a spiritual point of view (Plich 20062009). After healing the blind man, Jesus asks him about his faith ('Do you believe in the Son of Man?' [Jn 9:35]), and performs a second, spiritual healing of his sight, letting the already physically healed man see him as the Messiah, the Son of God. To the man's question: 'And who is he, sir, that I may believe in him?' (Jn 9:36), Jesus answers: 'You have seen him, and it is he who speaks to you' (Jn 9:37). The verb horao used here means 'to see fully', and it is only at this stage that the full meaning of the whole scene is revealed. After regaining his sight, the previously blind man worships Jesus; the word proskynesis, used to describe his reaction at this exact moment, means a deep bow of humbleness, which should be performed only in front of gods or rulers (Macalister \& Harrison 1979-1988; Tronina 1997).

The abovementioned cases have represented organic eye diseases, as it were, but in certain places in the New Testament blindness is seen differently. St Paul mentions etyflosen, people who are 'blinded' by the affairs of this world and who do not understand the message of the Gospel (2 Cor 4:3-4). St Paul says that pagan blindness makes them 'blaspheme God's name' (Rm 2:24). This is the first biblical mention that the weakness of perception negatively influences one's behaviour, and that it can have a moral dimension (Tronina 1997). One of the best-known examples of blindness in the New Testament is the temporary amaurosis of Saul that he experienced at the time of his conversion (Ac 9:3-9). He recognised the wrong that he had been doing against God, which became, for him, a blinding suddenness. His intense emotional conflict resulted in his inability to see his immediate future. It was a temporary form of blindness that was not caused somatically. Once his turbulent emotions had been calmed and his mind reoriented towards the spiritual light, Saul's own sight was restored. Figuratively, blindness represents a spiritual inability to discern and obey the will of 
God (cf. Is 42:16ff; 2 Cor 4:4; 2 Pt 1:9). Moreover, blindness can be conceived as an inability to perceive moral distinctions (Mt 15:14; 23:16ff) or biased moral judgement (Ex 23:8; Dt

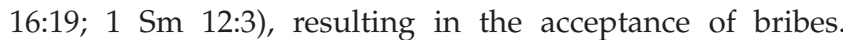
Blindness also denotes that spiritual impairment which makes one unable to understand God's prophecy (Is 29:9; cf. Jn 12:40) (Macalister \& Harrison 1979-1988).

\section{The story of Emmaus as an example of an interdisciplinary analysis}

The theology of the imperfections of human sight is best shown in the pericope about the meeting with the disciples going to Emmaus (Lk 24:13-35; Mk 16:12-13). The main question that arises here is why Jesus was not recognised by his own disciples. This question, in turn, opens up a wide range of issues and further questions, for example, why was Jesus recognised later, when breaking the bread? How to interpret the term 'their eyes were kept from recognising him' (Lk 24:16)? Although Jesus predicted his death and resurrection many times, his disciples fail to comprehend it. The spiritual blindness of the disciples still awaits a cure. They will need a second healing from Jesus in order to open their eyes fully to his identity and mission. Luke uses blindness and its healing as a major interpretive key to understanding the Gospel (Hartsock 2013). Jesus came in order to reverse this situation and teach both those who had spiritual sight and those who were spiritually blind (eds. Brand et al. 2003). The Evangelist Mark underlines the fact that Jesus has to open the spiritual eyes of his disciples so that they can fully understand his revelation (Schneider 1990).

Upon Jesus' trial and death, the disciples must have been distraught, traumatised and distressed, so could their state of mind and emotional disposition at that time have impacted on their ability to recognise the Person with whom they had previously stayed? It is not an overstatement to expect them to have been traumatised, shaken to the core, lost and confused. Contemporary empirical research may shed some new light on this problem. Paul et al. (2016) investigated the effect of stress on the discrimination of complex scenes and human faces. Whilst under stress, people had problems remembering and recognising the scenes of events, but they did not have the same problem with human faces. The authors explained this by saying that, from the neuropsychological point of view, stress has an effect on the functioning of the hippocampus, which plays a part in recognising the scenes of events, whilst the memory for faces is linked to an area of the temporal cortex, namely, the fusiform gyrus. On the other hand, there is a large body of evidence that indicates that a sense of danger has a profound effect on recognising human faces (e.g. Cutler, Penrod \& Martens 1987; Loftus, Loftus \& Messo 1987; Tooley et al. 2006). Moreover, it has also been discovered that simple misleading information can affect what we perceive and remember (Loftus \& Palmer 1974; Schacter \& Loftus 2013). To sum up, although there is no simple way of explaining why Jesus was not recognised by his disciples after his resurrection, there is some evidence to indicate that, in a situation of extensive stress, both perception and memory can be affected, making it difficult to identify scenes and people.

There is, however, a potential problem with attributing problems with identification only to factors such as stress, a sense of danger or even the experience of trauma. This is due to the stark difference in the accuracy between identifying familiar and unfamiliar people. Numerous research studies have established that, when identifying unfamiliar people, even in near-to-perfect conditions, we are likely to make many errors in identity (e.g. Bruce \& Young 1986; Burton 2013; McNeill, McNeill \& Strathie 2015; White et al. 2014; Young \& Bruce 2011). On the other hand, when we identify familiar people, we tend to make very few mistakes and in many situations our recognition is simply perfect (e.g. Jenkins et al. 2011; Kramer \& Reynolds 2018; Young \& Burton 2018). There is something that gives familiar faces a privileged ('special') status in the process of assigning someone's identity. World-renowned experts on facial identification agree that the crucial variability is whether the recognised faces are familiar or unfamiliar. The faces of people that we know are simply much easier to recognise and, interestingly, this is the case regardless of changes in their expressions, angles of sight or lighting. Taking all of this into consideration, it is difficult to explain why the disciples could not recognise someone whom they had known intimately for a few years. Moreover, it is even more puzzling that not even one of them recognised Jesus, whilst all of them knew him very well.

One of the problems with this interpretation is the fact that everybody who met Jesus post-resurrection struggled to recognise him. This transpires either explicitly or implicitly in all of the accounts across all four canonical Gospels. Other contemporary scholars (e.g. Neff 2020) argue that it was not caused by the mechanism of perception being faulty in all of the individuals who did not recognise Jesus, but that it was the Risen Jesus who was unrecognisable because he simply looked different to the way he looked before his death. Out of the 11 appearances after the resurrection that are presented in the Gospels, four clearly indicate that Jesus' appearance had changed (the meeting with the disciples on the Road to Emmaus in Mark and Luke; the meeting with Mary in the garden in John and with the disciples on the shore in John). Another four accounts implicitly suggest that Jesus' appearance had been altered after his resurrection (Jesus' appearance in the upper room in Luke and twice in John; and Jesus' Great Commission in Matthew). Neff (2020) also notes that only three out of the 11 post-resurrection accounts do not specifically mention Jesus' altered appearance; however, in some of them this can be implied, for example, Jesus' meeting with Mary in the garden in Matthew. These accounts, indeed, would be difficult to interpret as failings of human perception or as a stress-related and trauma-related dysfunction of both the cognitive and emotional processes.

The pericope cited here is one of the longest in the Gospel of Luke, and contains a great wealth of theological content, which is why it is worth trying to answer the question posed, taking into account the different contexts of contemporary 
inquiries of biblical exegesis. It presents many interpretive problems (Ehrhardt 1963; Ramelli 2014). Undoubtedly, for Luke, the story is clearly one of the most important, because it occupies one-half of the part of his Gospel dedicated to the resurrection (Lk 24). It is also recounted at far greater length and with far greater emphasis than any other version (Bowen 1910).

Although the disciples leave Jerusalem, they remain spiritually and mentally in the city. They cannot think or talk about anything else but that which happened in the recent past, and which had made a huge impression on them and caused a kind of fixation. This is indicated by a number of factors, one of which is the word homileo used by Luke to describe their conversation; notably, he uses this word twice. In the New Testament, the use of this word always signifies a great seriousness of conversation on a specific topic. In Acts 20:11, St Luke uses it in a liturgical context, with St Paul's solemn speech accompanying the rite of the breaking of the bread. In 24:15, Luke adds to this the word sydzetein, translated as 'talking and discussing together'. The disciples may have been absorbed by the conversation to such a great extent that they did not even notice the third interlocutor joining them and did not include him in the conversation. His presence, therefore, went unnoticed at first (Mickiewicz 2012).

The phrase that is used here is hoi oftalmoi auton ekratount, which can be translated as 'dimmed' or, in some other languages, 'captive'. The frequent verb krateo often means 'to take possession, control, grab, hold firmly, inhibit', hence these words are often used in a passive form: ekratounto, for example, being captured or held by an obstacle. The use of the passive ekratounto brings to mind the so-called passivum theologicum, or situations where something happens passively under the influence of God's action, for example, in Luke 5:20: 'Man, your sins are forgiven you'. It is a form that was also used earlier in Judaism to avoid using God's name. In that context, the interpretation can also indicate that it was Jesus himself who 'darkened' their eyes, since, as they said, they had already heard from the women that he was alive (v. 23). In that case, there may be the question raised as to why did they not recognise him? It is because Jesus himself did not allow them to recognise him, because he would not open their eyes until the events were fully explained (Mickiewicz 2012).

From an intellectual perspective, the disciples did not recognise Jesus when he joined them, because he first tries to reach their minds, not their senses. Using a somewhat complicated phrase, Jesus referred to them, saying 'what kind of ideas (thoughts) are you exchanging?' (tines hoi logoi houtoi hous antiballete pros allelous). Jesus' question causes his interlocutors to stop, both physically and intellectually, which, from a psychological point of view, can be interpreted as a large degree of astonishment and surprise. In addition, Luke uses the word skythropos to describe their deep sadness and gloom. Luke emphasised the great importance and symbolic significance of 'stopping' by rarely using verbs describing movement, which means that, after all the explanations made by Jesus, they would move forward only once they had learned the deep meaning of the events they were pondering, when they had freed themselves from overwhelming sadness and had started on a new stage of their journey. One of the disciples responded to Jesus in a way which is often commented on as being an expression of hidden aggression: 'You are probably the only one in Jerusalem who does not know what happened there'. Such an aggressive reaction does not seem to be justified because Jesus had not suggested with his question that he did not know what had happened in Jerusalem. He had simply shown interest in the topic of the conversation between the travellers. So, whilst at first the disciples had not noticed Jesus' presence at all, once they had noticed him, their first reaction to him seems reluctant, slightly hostile, and aggressive. Jesus himself, when questioned by his disciples about the meaning of the parables, replied that the parables should help the blind to see, whilst those who see will remain blind (e.g. Mt 13:10-17; Mk 4:10-12, 33-34). According to Jesus, 'seeing' is not so much physical or even rational, but rather affects the whole human being and requires an existential response (Schneiders 2016).

The gradual and slow nature of the opening of the eyes is described in the scene of Jesus washing the eyes of the blind man at the pool, where the blind man regained his sight gradually. If the opening of the physical eyes can be likened to obtaining knowledge, it could be said that both of these processes are gradual and that they take time. The biblical exegesis points out that Luke gradually and slowly reveals both the spiritual condition and the character of the personalities presented. After Jesus asks what they were discussing, they explain to him that Jesus was the one whom they followed and who was murdered; they summarise Jesus' mission and the events of the last few days. This description shows their great faith in Jesus, their devotion to, regard for and trust in him. They also recount that they believed that he was to 'free Israel', which signifies that their hopes associated with him were not only very robust, but also political. For this reason, when, in their account of events, Jesus comes to his death, they express not only their regret over what was done to him, but also what was done to their hopes; they became disappointed and disheartened (Mickiewicz 2012).

The speech that Jesus preaches, explaining the events to his disciples, or rather its beginning, is also symptomatic in the context of the issue discussed here. Jesus begins with a reprimand in which he calls the disciples anoetos (unintelligent, stupid or foolish) and bradys (lazy, blunt, slow). The significance of this rebuke is emphasised by the fact that such words are to be found nowhere else in Luke's Gospel, and, furthermore, that Luke, using at times material from Mark's Gospel, usually ignored any negative comments about the disciples (e.g. Mk 8:14-21 and Lk 12:1; Mk 32-33 and Lk 9:21-22). However, in this context he used strong words, referring to the disciples and accusing them of a 'lack of reason' and 'laziness of the heart'. Of course, these allegations 
are not just about the disciples not recognising Jesus but covering all of their reductionist and erroneous misconceptions: the political understanding of the Messiah's mission, and the hasty, selective and personalised reading of the prophetic scriptures. Undoubtedly, however, this results in a kind of relationship between their attitude, in this case a wrong one, and a certain inability to properly judge the reality that appears before their very eyes, one that can be perceived sensually and can even be easily read by others. After the rebuke, Jesus begins to explain to the disciples the passages in the Old Testament writings in which he is mentioned. He provides them with interpretations; literally, 'he explains to them' (diermeneusen autois), provides them with intellectual material, helps them make the mental association that the one who had died is also the same one who stands with them. He does so in order to help them understand that everything is as it should be, because the features of the Messiah whom they were waiting for are the features of the one whom they looked at, that is, he - Jesus Christ. It should be mentioned, however, that the messianic texts in the Old Testament were not easy or clear to read; they were general, and sometimes even ambiguous (Mickiewicz 2012).

Psychologists are divided according to their belief about the extent to which human perception relies on the information in the environment that is available to the senses. The two main proponents of these opposing theoretical approaches are Gibson (1966) and Gregory (1970). Gibson maintains that perception is a 'bottom-up' process that relies mainly on the simple perception of a stimulus that is reflected onto the retina and processed further along the visual pathway that ends in the brain's cortex. On the other hand, Gregory proposed an opposite explanation of the visual process called constructivism. According to this approach, it is the expectations and previous knowledge that guide the perception process; in other words, we will see what we expect to see, depending on our experience. That process is also called 'top-down', in order to reflect the importance of the higher cognitive processes in the act of perception. In this context, the fact that the disciples did not recognise Jesus means that their 'tethered eyes' can be understood in the context of their experience and knowledge of what had happened to Jesus. They saw Jesus suffering and dying on the cross, they saw him dead and buried, therefore they 'knew' it was not possible to see him alive. St Augustine also emphasises the disciples' strength of conviction, saying that they do not recognise Jesus as risen because they considered him dead (Serm. 236, 2).

A similar explanation of the perception process has been proposed by Pseudo-Dionysius the Areopagite, who claimed that there is a specific way of understanding reality. This, however, relates to a different aspect than that which the psychological approach focuses on, namely that it is a process that starts with a symbol (i.e. a material and physical reality) and arrives at an archetypal reality which the symbol reveals. Entering from what is 'below' to what is 'above', PseudoDionysius opposed the Platonic category of 'inside/outside', according to which outside, physical things can be understood, provided a deep introspection is present. It is also worth mentioning that this Platonic concept was eagerly developed by different Christian thinkers and mystics (e.g. Origen, Gregory of Nyssa, Augustine, and the medieval mystics), who described the progress made on the way of getting to know something in terms of delving into one's own interior (Gawrilyuk \& Coakley 2012).

According to Maximus the Confessor, there is a close relationship between the senses and the intellect. Although they have their individual and separate goals, intelligence and sensuality do not remain in conflict. Rather, they are naturally related via a power connection that unites them. There are numerous connections between the intellect and what it perceives, as well as between the senses and what they experience. Maximus describes three interrelated movements of 'the self' which underlie the deep relationship between perceptual knowledge and theological anthropology. That configuration entails three modalities of cognition: (1) by the mind (nous), (2) by discursive reason (logos), and (3) by sensory perception (aistesis). Each one of these is marked with its own natural movement, but the goal of each of these movements is to reintegrate the human 'self'. That is why the powers of the senses and reason are correlated and interrelated with each other via the mind, a spiritual subject that has 'an unwavering power' to unite them (Louth 1996).

We do not know why the disciples did not recognise Jesus even after his explanation, but Luke 24:32 ('Did not our hearts burn within us whilst he talked to us on the road, whilst he opened to us the scriptures?') indicates that, indeed, they did not recognise Jesus even then, and that their eyes 'were not yet open'. One more experience was needed for sight to fulfil its role, for them to believe in the one they saw. The disciples recognised Jesus only when he was breaking the bread (Bowen 1910). The question that arises here is why they recognised him only then and not earlier, when he was talking to them and they looked at him. The latest interpretations indicate that: (1) only then did the disciples see the wounds on Jesus' hand, (2) they got to know him on the basis of the prayer specific only to him when he was breaking bread (J. Plummer, H. Langkammer), (3) there is a supernatural element in Jesus performing the first and true Eucharistic supper for the disciples after the Resurrection (e.g. W. Bartelt, J. Dupont, K. Lehmann). The supernatural explanation is the most common hypothesis in contemporary exegetes (e.g. W. Eckey, F. Hauck, E. Klostermann, K. Staab), because it occurs in a passive voice (the phrase is auton de dienoichthesan hoi ofthalmoi - 'their eyes have been opened'). It is because of this supernatural power that they can fully see and recognise Jesus, the Risen Lord, in their travelling companion. The moment when they finally recognise him, something unexpected happens, in that he becomes invisible to them. The term used here to describe this (afantos) does not imply that Jesus left his disciples, but rather ceased to be perceived by them sensually, that henceforth he would be known only via faith (Mickiewicz 2012). 


\section{Conclusion: Perceptual disability from a theological, philosophical and psychological perspective}

The theology of the defect of human perception is obviously related to the sin that disturbs all human internal and external faculties. According to St Augustine, original sin has caused all human sensual cognition to become decayed and dysfunctional, as a result of which the whole of humanity remains in a state of 'sensual exile'. The dysfunction of the spiritual and all other senses leads to a multifaceted disharmony in the human being, and ultimately to a lack of happiness. The spiritual dysfunction caused by sin also extends to the bodily senses. Although people share sensory experiences with the animal world, St Augustine notes an interesting difference here, namely the difference in the bodily structure of humans and animals. He claims that man was created in an upright position to enable him to look forward and upward in order to be able to look to heaven and God. In this way, the human body has already been shaped in such a way that allows it to make optimal use of its bodily senses. Because of sin, however, the body is now bent and the senses located in it are now directed downwards to the ground. For instance, whilst walking we tend to look mostly at the ground. Augustine interprets the parable of the feast (Lk 14:15-24), where the main character declines an invitation to a feast by saying that that he must examine his new five yoke of oxen, as an allegory. These five pairs of oxen, according to St Augustine, are a metaphor for man's attachment to the sensual perceptions associated with the five senses. St Augustine extensively describes the pernicious effect of the bodily sensations on the soul, and he associates it with two reasons: (1) because they have been contaminated with sin, and (2) because the soul becomes quickly attached to these sensations, which is also a direct result of sin, as well as to the dysfunction of the perception of the external senses. The soul, surrendering to the imposed, deceptive influence of the external senses, ceases to be the agent, the subject acting in a sensual experience, but instead is forced to learn only through lust (libido), whilst its real 'partner' and support in acquiring true knowledge is only mens, intellectus. St Augustine has based his argument on the story of the Samaritan woman who had five husbands (cf. Jn 4:16-18), and, similarly, the soul 'gets married' to each of the five senses and, finally, the soul commits adultery instead of giving herself to the real husband, who is the intellectus. On the other hand, the philosophical aspects of the issue are too numerous to be discussed in this text. It is important to point out, however, that, when it comes to inquiring about the impairment of sight, of the senses in general, and of the entire perception process, psychologists and philosophers who enquire deeper into these issues, especially philosophers of religion, should know that they are already dealing with theology, for example Augustinus, In Johannis evangelium tractatus and De diversis questionibus (Corpus Christianorum Series Latina n.d.).
Similarly, theologians, wanting to better understand their areas of research, are beginning to discover their philosophical aspects. This is necessary in modern times, as many areas of life and science are atomised and focused on very small specialisation fields. It would seem that the topic discussed in this text indicates this even more, and an interdisciplinary approach is not only beneficial but even necessary in order to understand the nature of sensory dysfunction. The philosophical dimension of the issue under consideration here appears in discussions on the relationship between perception and virtue (epistemology and ethics). For example, Origen noted that as man builds an ever-closer relationship with God, his physical senses, never mind the spiritual ones, undergo a transformation. According to Maximus the Confessor, perception is a gradual reality that integrates and immerses a person into God's life, little by little.

The contemporary writers Roberts and Wood (2007) say that the functioning of the senses and the intellect is deeply saturated with will. The efficiency of sensual cognition, together with its rational element, 'is equally a matter of love, worries, desires, emotions and the like, similar to other areas of our existence' (Roberts \& Wood 2007:10). Another philosophical aspect of the issue under discussion here is the theory of illumination. Both in Plato's metaphysics and in his psychology, and later in Aristotle's writings, 'light' is seen as a paradigm of all knowledge. Light is also crucial for the mind, that is, for clarity of thinking, for gaining, arranging and retrieving knowledge. This analogy was then taken up by Christian teaching (e.g. by Philo, Origen and Augustine) but was developed in particular by Pseudo-Dionysius the Areopagite, who used the term 'illumination' in order to refer to the mind in countless contexts and replace it with many synonyms. The author repeatedly points out that he meant transcendent light (hyperusion) and noetic light (noeton) rather than physical light. Illumination is, therefore, a broad doctrine that touches upon the issue discussed here in the following matters: (1) because God is the source of all being, only he is the source of all 'illumination', (2) God's illumination gives all intelligent creatures the opportunity to learn, (3) only God can make dark things light and (4) only God cleanses 'the eye of the mind' and removes the errors that are a natural and inherent part of perception.

This article has indicated that the problem of assessing the imperfection of human perception is not a modern scientific research area but an issue that has been raised since antiquity. The distortions of the human perception of reality and its interpretation, as this article has demonstrated, is not only a question of the biological functioning of the individual senses, but goes deeper, into human nature and its theological dimension. The essence of our research is to show the interdisciplinary nature of this issue and to open up a discussion on this topic in other areas of scientific enquiry, which, due to the limited nature of our research, have not been included here. This article proves that the theological interpretations of the defects in human perception, linked 
to the effects of original sin, are not enough to fully understand the problems haunting human perception. By the same token, neither a philosophical investigation of the truth about human nature, nor an understanding of the mechanisms governing human perception from the point of view of psychology or neurobiology, can do so. Only the combination of many scientific methodologies and points of view can bring us closer to understanding the complexity of the problem under discussion and open up space for further research.

\section{Acknowledgements Competing interests}

The authors have declared that no competing interests exist.

\section{Authors' contributions}

All authors contributed equally to this work.

\section{Ethical consideration}

This article followed all ethical standards for a research without direct contact with human or animal subjects.

\section{Funding information}

The project is funded by the Minister of Science and Higher Education within the programme 'Regional Initiative of Excellence' in 2019-2022, project number: 028/RID/2018/19, amount: 11742500 PLN.

\section{Data availability statement}

Data sharing is not applicable to this article as no new data were created or analysed in this study.

\section{Disclaimer}

The views and opinions expressed in this article are those of the authors and do not necessarily reflect the official policy or position of any affiliated agency of the authors.

\section{References}

Aristotle, 1933, Metaphysics, 1.980a, transl. H. Tredennick, vol. 17 \& 18, Harvard University Press, Cambridge.

Bowen, C.R., 1910, 'The Emmaus disciples and the purposes of Luke', The Biblical World 35(4), 234-245. https://doi.org/10.1086/474319

Brand, C., Draper, C., England, A., Bond, S., Clendenen, E.R., Butler, T.C. et al (eds.), 2003, Holman illustrated Bible Dictionary, Holman Bible Publishers, Nashville, TN.

Bruce, V. \& Young, A., 1986, 'Understanding face recognition', British Journal of Psychology 77(3), 305-327. https://doi.org/10.1111/j.2044-8295.1986. tb02199.x

Burton, A.M., 2013, 'Why has research in face recognition progressed so slowly? The importance of variability', The Quarterly Journal of Experimental Psychology 66, 1467-1485. https://doi.org/10.1080/17470218.2013.800125

Corpus Christianorum Series Latina (CCSL), n.d., Brepols, viewed 18 Decembe 2019, from http://www.brepols.net/Pages/BrowseBySeries.aspx?TreeSeries= CCSL.
Cutler, B.L., Penrod, S.D. \& Martens, T.K., 1987, 'Improving the reliability of eyewitness identification: Putting context into context', Journal of Applied Psychology 72(4), 629-637. https://doi.org/10.1037/0021-9010.72.4.629

Ehrhardt, A., 1963, 'The disciples of Emmaus', New Testament Studies 10, 182-201. https://doi.org/10.1017/\$0028688500002769

Gawrilyuk, P.L. \& Coakley, S., 2012, The spiritual senses, perceiving God in Western Christianity, Cambridge University Press, Cambridge.

Gibson, J.J., 1966, The senses considered as perceptual systems, Houghton Mifflin, Boston, MA.

Gregory, R., 1970, The intelligent eye, Weidenfeld and Nicolson, London.

Hartsock, C., 2013, 'Blindness and deafness', in J.B. Green, J.K. Brown \& N. Perrin (eds.), Dictionary of Jesus and the Gospels, 2nd edn., pp. 90-91, IVP Academic, Downers Grove, IL.

Hull, J.M., 2001, In the beginning there was darkness: A blind person's conversations with the Bible, Trinity Press International, Harrisburg, PA.

Jenkins, R., Van Montfort, X., White, D. \& Burton, A.M., 2011, 'Variability in photos of the same face', Cognition 121(3), 313-323. https://doi.org/10.1016/j. cognition.2011.08.001

Kramer, R.S.S. \& Reynolds, M.G., 2018, 'Unfamiliar face matching with frontal and profile views', Perception 47(4), 414-431. https://doi.org/10.1177/030100 6618756809

Loftus, E.F., Loftus, G.R. \& Messo, J., 1987, 'Some facts about "weapon focus"', Law and Human Behavior 11(1), 55-62. https://doi.org/10.1007/BF01044839

Loftus, E.F. \& Palmer, J.C., 1974, 'Reconstruction of automobile destruction: An example of the interaction between language and memory', Journal of Verbal Learning \& Verbal Behavior 13(5), 585-589. https://doi.org/10.1016/S0022 5371(74)80011-3

Louth, A., 1996, Maximus the Confessor (The Early Church Fathers), Routledge, London.

Macalister, A. \& Harrison, R.K., 1979-1988, 'Blindness', in G.W. Bromiley (ed.), The International Standard Bible Encyclopedia (Revised), pp. 525-526, Eerdmans, Grand Rapids, MI.

Majid, A., Roberts, S.G., Cilissen, L., Emmorey, K., Nicodemus, B., O'Grady, L. et al., 2018, 'Differential coding of perception in the world's languages', Proceedings of the National Academy of Sciences 115(45), 11369-11376. https://doi. of the National Academy of
org/10.1073/pnas.1720419115

McNeill, A., McNeill, M. \& Strathie, A., 2015, 'Expert facial comparison evidence: Science versus pseudo science', Psychology and Law 5(4), 127-140. https://doi. org/10.17759/psylaw.2015050411

Mickiewicz, F. (ed.), 2012, 'Nowy komentarz biblijny', Nowy Testament III(2), 590-599.

Neff, C., 2020, 'In a different form: The unrecognizable Jesus of the post-resurrection tradition', viewed 10 December 2019, from https://www.academia. edu/39141193/In_A_Different_Form_The_Unrecognizable_Jesus_of_the_PostResurrection_Tradition.

Paul, M., Lech, R., Scheil, J., Dierolf, A., Suchan, B. \& Wolf, O.T., 2016, 'Acute stress influences the discrimination of complex scenes and complex faces in young healthy men', Psychoneuroendocrinology 66, 125-129. https://doi.org/10.1016/j. psyneuen.2016.01.007

Plich, J.J., 2006-2009, 'Blindness', in K.D. Sakenfeld (ed.), The new interpreter's dictionary of the Bible, vol. 1-5, p. 480, Abingdon Press, Nashville, TN.

Ramelli, L., 2014, 'The Emmaus disciples and the Kerygma of the Resurrection (Lk 24 , 34)', Zeitschrift für die Neutestamentliche Wissenschaft und Kunde der Älteren Kirche 105(1), 1-19. https://doi.org/10.1515/znw-2014-0001

Roberts, R.C. Wood, W.J., 2007, Intellectual Virtues: An Essay in Regulative Epistemology, Oxford University Press, New York.

Schacter, D. \& Loftus, E., 2013, 'Memory and law: What can cognitive neuroscience contribute?', Nature Neuroscience 16(2), 119-123. https://doi.org/10.1038/ $\mathrm{nn} .3294$

Scharge, W., 1985, 'Thyplos', in G. Kittel, G. Friedrich \& G.W. Bromiley (eds.) Theological Dictionary of the New Testament, VIII, pp. 270-294, Eerdmans, Grand Rapids, MI.

Schneider, G., 1990, 'Blindness', in H.R. Balz \& G. Schneider (eds.), Exegetical dictionary of the New Testament, pp. 377-378, Eerdmans, Grand Rapids, MI.

Schneiders, S.M., 2016, 'Biblical spirituality', Interpretation: A Journal of Bible and Theology 70(4), 417-430. https://doi.org/10.1177/0020964316655108

Tooley, V., Brigham, J., Maass, A. \& Bothwell, R., 2006, 'Facial recognition: Weapon effect and attentional focus', Journal of Applied Social Psychology 17, 845-859. https://doi.org/10.1111/j.1559-1816.1987.tb00294.x

Tronina, A., 1997, Panie, Abym przejrzał! Ślepota i niewidomi w Biblii, Redakcja Wydawnictw Katolickiego Uniwersytetu Lubelskiego, Lublin.

White, D., Kemp, R.I., Jenkins, R., Matheson, M. \& Burton, A.M., 2014, 'Passport officers' errors in face matching', PLoS One 9(8), e103510. https://doi. org/10.1371/journal.pone.0103510

Young, A. \& Bruce, V., 2011, 'Understanding person perception', British Journal of Psychology 102(4), 959-974. https://doi.org/10.1111/j.2044-8295.2011.02045.x

Young, A. \& Burton, A.M., 2018, 'Are we face experts?', Trends in Cognitive Science 22(2), 100-110. https://doi.org/10.1016/j.tics.2017.11.007 